\title{
Subsidiary Role and Skilled Labour Effects in Small Developed Countries
}

\author{
Jens Gammelgaard · Frank McDonald · Heinz Tüselmann · Christoph \\ Dörrenbächer · Andreas Stephan
}

\section{Abstract and Key Results:}

- This paper considers the proportion of skilled labour employed by subsidiaries in small countries in the context of the strategic role of subsidiaries. Strategic role is connected to autonomy and intra-organisational relationships and the mandates given to the subsidiary. In the paper, we draw on the literature on the strategic development of multinational corporations, and insights from inward foreign direct investments in small developed countries. This is presented in a unifying framework in order to predict diverse categorizations of the impact of subsidiary role on the proportion of their employment of skilled labour.

- The paper derives two propositions that postulate interactions between three roles containing different levels of autonomy and intra-organisational relationships in small developed countries that lead to different proportions of skilled labour in subsidiaries.

- We predict the highest proportion of skilled labour by subsidiaries located in small developed countries in the case of world mandates when autonomous-based operations are emphasized. When there is an emphasis on intra-organizational relationships, measured by product flows and integrated international value-chain configurations, we predict the proportion of skilled labour to be highest in the cases of specialized contributors. We propose the proportion of skilled labour to be lowest in the case of local implementers.

Keywords: Subsidiary Roles · Small Developed Countries · Employment $\cdot$ Skilled Labour · Autonomy $\cdot$ Intra-Organisational Relationships

Received: 01.02.2008 / Revised: 01.04.2008 / Accepted: 01.05.2008

(C) Gabler-Verlag 2009

Associate Professor J. Gammelgaard $(\bowtie)$

Department of International Economics and Management, Copenhagen Business School,

Copenhagen, Denmark.

Professor F. McDonald

Bradford Centre in International Business, Bradford University School of Management, Bradford, United Kingdom.

Professor H. Tüselmann

Centre of International Business and Innovation, Manchester Metropolitan University, Manchester, United Kingdom.

Assistant Professor C. Dörrenbächer

Department of International Business and Management, University of Groningen, Groningen, Netherlands.

Associate Professor A. Stephan

Jönköping International Business School, Jönköping University, Jönköping, Sweden. 